\title{
Smart tools of urban climate evaluation for smart spatial planning
}

\author{
Hana STŘEDOVÁ a*, Tomáš STŘEDA a , Tomáš LITSCHMANN ${ }^{\text {b }}$
}

\begin{abstract}
Air temperature and humidity conditions were monitored in Hradec Králové, Czech Republic, by a network of meteorological stations. Meteorological sensors were placed across a representative variety of urban and suburban environments. The data collected over the 2011-2014 period are analysed in this paper. The data from reference standard meteorological stations were used for comparison and modelling purposes. Air temperatures at the points of interest were successfully modelled using regression relationships. The spatial expression of point measurements of air temperatures was provided by GIS methods in combination with CORINE land cover layer, and satellite thermal images were used to evaluate the significance of these methods. The use of standard climate information has low priority for urban planners. The impact of the urban heat island on city residents and visitors was evaluated using the HUMIDEX index, as it is more understandable for urban planners than temperature conditions as such. The aim of this paper is the modification, description and presentation of urban climate evaluation methods that are easily useable for spatial planning purposes. These methods are based on comprehensible, easily available but quality data and results. This unified methodology forms a theoretical basis for better urban planning policies to mitigate the urban heat island effects.
\end{abstract}

Keywords: urban heat island, city development plan, HUMIDEX, Hradec Králové, Czech Republic

\section{Introduction}

The urban population in 2014 accounted for $54 \%$ of the total global population, and is expected to grow by approximately $1.64 \%$ per year between 2015 and 2030 . The rate of urbanization is especially important for low- and middle-income countries, as $70 \%$ of the world population is forecasted to live in cities by 2050 (WHO, 2013). From this point of view, urban climate research ranks highly as a current topic in recent climatology, largely due to the growing number of city inhabitants together with the significant effects of climatic conditions on their health and the risk of damages caused by extreme weather events.

In the case of air temperature, the city centre could be about several degrees centigrade warmer than suburban landscapes. It directly influences not only human health but also causes negative economic consequences (Oke, 1997). The urban heat island is a function of meteorological factors (air temperature, precipitation, solar radiation, cloud cover, air flow, evapotranspiration, etc.) and the character of the city itself: the number of inhabitants and population density; topography; altitude; water bodies; land cover - built-up area; surface colour - their albedo; distances between buildings; building heights; surface resistance; the surface geometry of the city - the so-called "street canyon"; the "anthropogenic heat" of heating and industry; surface retention; the thermal capacity of materials; thermal conductivity and humidity, etc. (Oke, 1997; Voogt, 2002; Landsberg, 1981). The urban heat island effect becomes stronger during warm, windless and cloudless days (Oke, 1982). An urban area with a unique temperature regime (e.g. due to parking lots, industrial objects, flat roofs, asphalt roads, etc., i.e. isolated urban locations that produce "hot spots" within a city) is occasionally referred to as a "micro-urban heat island" (Aniello et al., 1995; Ekşi and Uzun, 2013; Smargiassi et al., 2009; Stathopoulou et al., 2004).

Knowledge of local geographical conditions and the surface temperature regime allows for the identification of places with thermal and/or thermodynamically-related local climatic effects (Vysoudil et al., 2009). Ellefsen (1991) identified 17 types of urban terrain zones (UTZ) to classify the physical structure of cities. The method of urban morphometry, that uses aerial photography, is applicable to cities all over the world. Oke (2006) designed a simple and generic classification of city zones to improve the siting of meteorological instruments in urban areas. A simplified classification of distinct urban forms according to their ability to impact local climate is used to divide city terrain into seven homogenous regions called "urban climate zones" - UCZ (Srivanit, 2013). The "local climate zone" (LCZ: Stewart and Oke, 2012) classification system provides a research framework for urban heat island studies and standardizes the worldwide exchange of urban temperature observations. Lehnert et al. (2014) have set up a classification of existing stations within local climate zones (LCZ) for conditions of the Czech Republic.

Vysoudil and Ogrin (2009) present some possibilities of application of a portable infrared camera for topoclimatic research, especially for establishing the differences in temperatures of the active surface layer. The impact of relief is expressed in a much higher urban heat island intensity in a city located in a valley bottom (including the city centre) than in cities of comparable size but located in flat areas (Bokwa, 2011). Satellite images, radar measurements and aviation technology are widely used for studying urban

\footnotetext{
a Mendel University in Brno, Faculty of Agronomy, Brno, Czech Republic (*corresponding author: H. Středová, e-mail: hana.stredova@mendelu.cz)

${ }^{\mathrm{b}}$ AMET, Velké Bílovice, Czech Republic
} 
climates (e.g. Voogt and Oke, 2003). Aerial and satellite imagery can help researchers describe surface heterogeneity and its influence on microclimate.

The quantification of urban heat island effects on mesoclimate, and their possible influence on human beings with respect to the size of the agglomeration, the level of built-up areas and features of their surfaces etc., is a principal current research question. Significant spatial variability in the environment is the main obstacle to modelling the urban climate because the natural surface vegetation overlaps infrastructure and buildings. Bottyán and Unger (2003) and Souch and Grimmond (2006) claimed that besides meteorological conditions (radiative or advective), factors such as the characteristics of the builtup area, land use, topography and the presence of large water bodies, markedly shape the spatial differentiation of meteorological elements in a city.

The negative influence of the urban heat island on the microclimate will likely increase. Urban development standards need to be created by using existing knowledge and developing tools for urban planning over long-term periods (Jendritzky et al., 2003). This study provides knowledge of standard and advanced microclimatic monitoring methods as a helpful tool for urban planning.

\section{Study rationale}

The relations between extreme weather situations (extreme temperatures, heat waves, etc.) and particular health complications for a city's inhabitants are clear. An evaluation of satellite thermal images and mortality data showed that a direct connection exists between mortality risk and high surface temperatures on extremely hot days. Mortality is strongly associated with the duration of heat waves in summer, demonstrated in many locations: Tan et al. (2007) for Shanghai; Karl and Knight (1997) for Chicago; Dessai (2002) for Lisbon; Schär et al. (2004) for Paris; and Smargiassi et al. (2009) for micro urban heat islands in Montreal. The effect of relief and land use on heat stress in Kraków (Poland) was evaluated by Bokwa and Limanówka (2014). These authors' results suggest that in cities located on concave landforms, relief is at least as equally important as land use in controlling the spatial pattern of heat stress. Pokladníková et al. (2009) demonstrated another significant characteristic of the urban climate in which heat waves are more frequent and longer compared with suburban areas, based on a study of medium-sized cities in the Czech Republic. Středa et al. (2014) analysed the number of "hot wave" days in Hradec Králové from 1961 to 2007; such days increased by two days per decade. The term "heat wave" is relative to the climatic conditions at a specific location. Therefore, the World Meteorological Organization recommended that a heat wave be defined as the period during which the daily maximum air temperature over five consecutive days is at least $5{ }^{\circ} \mathrm{C}$ higher than the normal average daily maximum for a given period (Frich et al., 2002). The frequency, intensity and duration of heat waves did not generally increase during the $20^{\text {th }}$ century. In the $21^{\text {st }}$ century, however, and particularly in the second half, the situation will likely be dramatically altered.

Traditional studies of heat islands typically do not include bioclimatic aspects; therefore, these studies are of limited use to urban planners. An evaluation of the effects of anthropogenic changes on the thermal environment that are related to human health and wellbeing is needed (Jendritzky and Nübler, 1981). Numerous indices can evaluate the influence of temperature, moisture and wind on human bodies. For example, d'Ambrosio Alfano et al. (2011) proposed the main comfort and stress indices caused by the thermal environment. In addition to temperature- and moisture-based indices, more complex indices account for factors such as wind speed and global radiation. The use of these metrics, however, is limited by the wide variability in these factors in the urban environment (e.g. shaded or sunny streets, perpendicular or parallel to wind direction, etc.).

Appropriate urban planning and building design provides measures to reduce heat stress for individuals living in cities and reduces the urban heat island effect. The heat load becomes more extreme if the human body is directly irradiated by solar radiation. Planning measures that provide shade for pedestrians (e.g. trees, arcades and narrow streets) can therefore reduce the heat load (Jendritzky, 1988). Szűcs (2013) investigated the extent to which urban planning and the resulting morphology of the built environment in Dublin influenced the microclimate that was created by the wind regime.

To maximize thermal comfort in urban areas, climatic aspects should be considered at all scales, from the design of individual buildings to regional planning. The type of housing, its density and optimal distances between buildings, the geometric configuration and orientation of buildings, building heights, the properties of the building materials and colours of external surfaces, the orientation and size of windows, settlement shading and radiation control, the use of open space, and the functions and location of land use, all of these factors might be considered during the urban planning process to improve the urban microclimate (Koppe et al., 2004).

Microclimate tools have recently been used for the simulation of microclimate in urban conditions, with respect to the cooling effects of greening on urban microclimates, but in-situ measurements of meteorological conditions for model verification are necessary. Some possible uses of numerical microclimate simulation tools (ENVI-met) for urban spatial planning have been described for instance by Srivanit and Hokao (2013). The average maximum temperature would be decreased and be reduced by as much as $2.27^{\circ} \mathrm{C}$ in the peak of the summer when the quantity of trees was increased by $20 \%$. Similarly, an analysis in the United States on the potential of vegetation to reduce summer cooling loads in residential buildings in cities found that an additional 25\% increase in urban tree coverage saved $40 \%$ of the annual cooling energy cost in Sacramento (Huang et al., 1987).

The development of Hradec Králové was planned by the architect Josef Gočár (1880-1945) in the early 1920s. His regulation of the city, which commenced in 1925, included the concept of using a significant amount of green spaces. The implementation of the city development plan was recently addressed in an evaluation of the impact of land cover changes on the city microclimates. Therefore, the results from the current study might be a helpful tool for urban planning in Hradec Králové and for preparing regional city planning in areas with similar conditions. Stewart (2011), however, has warned us that "If climate modelers, weather forecasters, city planners, urban engineers and building architects are to be convinced of the serious environmental and social implications behind the urban heat island effect, heat island researchers must first produce results that can be trusted". Such results should be based on comprehensible, easily available but reliable quality data. 
They can be used when public vegetation planning and nurturing is under discussion, as well as for negotiations with other administrative bodies (the river authorities, the road and motorway directorate, energy companies, etc.).

\section{Data and methods}

Hradec Králové is a city with a population of nearly one hundred thousand inhabitants and an area of $105.6 \mathrm{~km}^{2}$, which makes it among the ten largest cities in the Czech

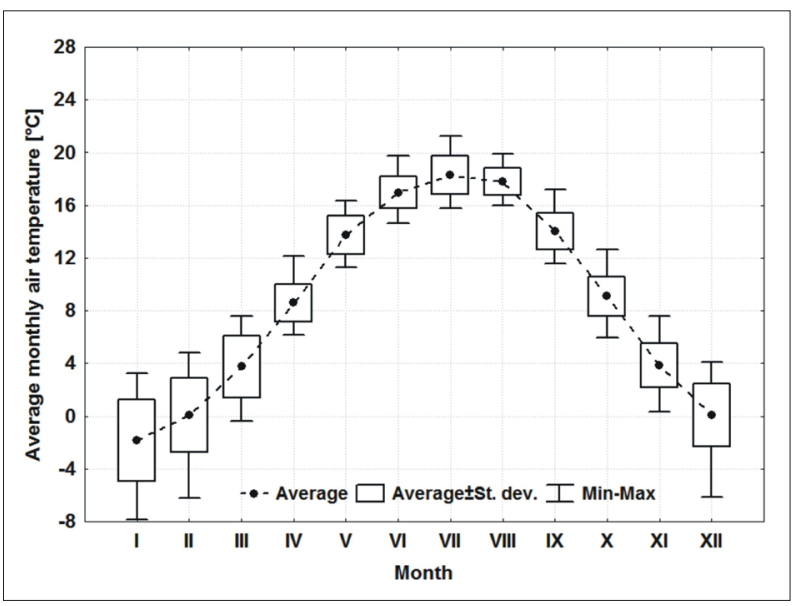

Fig. 1: Mean annual temperature in Hradec Králové during the period 1961-1990.

Source: Czech Hydrometeorological Institute
Republic. The landscape is predominantly flat with an average altitude of $235 \mathrm{~m}$ a.s.l. The mean annual temperature (1961-1990) is $8.7^{\circ} \mathrm{C}$, and the mean annual total precipitation is $600.2 \mathrm{~mm}$. The warmest months are July $\left(18.3^{\circ} \mathrm{C}\right)$ and August $\left(17.8^{\circ} \mathrm{C}\right)$ (Fig. 1). The ALADIN-Climate/CZ model predicted for the simulation period 2021-2050 an increase in the mean annual temperature of up to $9.9^{\circ} \mathrm{C}$. August was predicted to be the warmest month, with a mean temperature of $21.0^{\circ} \mathrm{C}$. The surrounding area is dominated by arable land and suburban forests, such that the area of green vegetation per inhabitant is one of the highest among large Czech cities. In addition, the confluence of the Labe and Orlice Rivers in the city centre significantly influences surrounding climatic conditions.

\subsection{Evaluation of urban (bio)climatic conditions as a five-step process}

Step I: A network of spatial monitoring points was established in Hradec Králové in August 2011 to analyse the influence of surface properties (land cover and land use) and their horizontal effects on temperature and humidity conditions (Tab. 1; for geographic locations, see Fig. 6). Temperature and humidity were monitored using sensors located across a representative variety of urban and suburban environments. The special network used U23 HOBO Pro V2 sensors located within a radiation shield at a height of two meters above the ground. The measurement interval at all stations was ten minutes.

\begin{tabular}{|c|c|c|c|c|c|}
\hline $\begin{array}{l}\text { Location of } \\
\text { measurement }\end{array}$ & Label & $\begin{array}{c}\text { Brief characteristics of the } \\
\text { environment }\end{array}$ & $\begin{array}{l}\text { Ellefsen } \\
\text { (1991) UTZ } \\
\text { classification }\end{array}$ & $\begin{array}{l}\text { Stewart and } \\
\text { Oke }(2012) \text { LCZ } \\
\text { classification }\end{array}$ & $\begin{array}{l}\text { Oke (2006) } \\
\text { UCZ } \\
\text { classification }\end{array}$ \\
\hline $\begin{array}{l}\text { Industrial zone } \\
50^{\circ} 11^{\prime} 43.159^{\prime \prime} \mathrm{N} \\
15^{\circ} 51^{\prime} 18.336 " \mathrm{E}\end{array}$ & 1 & $\begin{array}{l}\text { significant proportion of horizontal } \\
\text { concrete and asphalt surfaces, partial } \\
\text { grassland, sunlit spaces all day }\end{array}$ & Do4 & $\begin{array}{l}\text { LCZ 8 (large low-rise } \\
\text { with scattered trees) }\end{array}$ & UCZ 4 \\
\hline $\begin{array}{l}\text { City park } \\
50^{\circ} 12^{\prime} 21.884 " \mathrm{~N}, \\
15^{\circ} 49^{\prime} 31.925^{\prime \prime} \mathrm{E}\end{array}$ & 2 & $\begin{array}{l}\text { woody vegetation in the city centre, } \\
\text { grass cover, full shade, near the con- } \\
\text { fluence of two major rivers }\end{array}$ & Unclassifiable & $\begin{array}{l}\text { LCZ B (scattered trees } \\
\text { land cover type) }\end{array}$ & Unclassifiable \\
\hline $\begin{array}{l}\text { Suburban forest } \\
50^{\circ} 10^{\prime} 39.974^{\prime \prime} \mathrm{N} \\
15^{\circ} 54^{\prime} 14.036^{\prime \prime} \mathrm{E}\end{array}$ & 3 & $\begin{array}{l}\text { middle-aged, predominantly conife- } \\
\text { rous forest, shaded by trees (except in } \\
\text { the afternoon), absence of significant } \\
\text { artificial surfaces }\end{array}$ & Unclassifiable & $\begin{array}{c}\text { LCZ A (dense trees land } \\
\text { cover type) }\end{array}$ & Unclassifiable \\
\hline $\begin{array}{l}\text { Historic city centre } \\
50^{\circ} 12^{\prime} 39.493^{\prime \prime} \mathrm{N} \\
15^{\circ} 49^{\prime} 55.767 " \mathrm{E}\end{array}$ & 4 & $\begin{array}{l}\text { the historical part of the city centre, } \\
\text { enclosed area (courtyard) with verti- } \\
\text { cal surfaces and limited air flow, ar- } \\
\text { tificial solid surfaces, insolation from } \\
\text { morning until afternoon }\end{array}$ & $\mathrm{A} 2$ & $\begin{array}{l}\text { LCZ } 3_{2} \text { (compact low-rise } \\
\text { with mid-rise built type) }\end{array}$ & UCZ 2 \\
\hline $\begin{array}{l}\text { Urban residential zone } \\
50^{\circ} 12^{\prime} 52.516^{\prime \prime} \mathrm{N} \\
15^{\circ} 49^{\prime} 32.781^{\prime \prime} \mathrm{E}\end{array}$ & 5 & $\begin{array}{l}\text { location surrounded by residential } \\
\text { buildings five stories high, woody and } \\
\text { shrubby vegetation in the immediate } \\
\text { vicinity of the measurement location, } \\
\text { grass cover, small summer swimming } \\
\text { pool, partially sunlit afternoons }\end{array}$ & De3 & $\begin{array}{l}\mathrm{LCZ} 2_{\mathrm{B}} \text { (compact mid- } \\
\text { rise with scattered trees) }\end{array}$ & UCZ 3 \\
\hline $\begin{array}{l}\text { Reference } \\
\text { climatological location } \\
50^{\circ} 13^{\prime} 21.367^{\prime \prime} \mathrm{N} \\
15^{\circ} 47^{\prime} 15.969^{\prime \prime} \mathrm{E}\end{array}$ & 6 & $\begin{array}{l}\text { located according to the principles of } \\
\text { meteorological station establishment, } \\
\text { the sensors are placed in a meteorolo- } \\
\text { gical shelter }\end{array}$ & Do3 & $\begin{array}{l}\text { LCZ } 9 \text { (sparsely built } \\
\text { - built type) }\end{array}$ & UCZ 5 \\
\hline $\begin{array}{l}\text { Reference } \\
\text { climatological location } \\
50^{\circ} 10^{\prime} 39.01^{\prime \prime} \mathrm{N} \\
15^{\circ} 50^{\prime} 18.98^{\prime \prime} \mathrm{E}\end{array}$ & 7 & $\begin{array}{l}\text { located according to the principles of } \\
\text { meteorological station establishment, } \\
\text { the sensors are placed in a meteorolo- } \\
\text { gical shelter }\end{array}$ & Do3 & $\begin{array}{l}\text { LCZ } 9 \text { (sparsely built } \\
\text { - built type) }\end{array}$ & UCZ 5 \\
\hline
\end{tabular}

Tab. 1: Location of the measurement stations and characteristics of the environment Source: authors and references in heading 
Data from standard meteorological stations of the Czech Hydrometeorological Institute (CHMI) were used as reference points. The CHMI stations at Locality 6 and Locality 7 are standard meteorological stations at which the air temperature and humidity are monitored at a height of two meters above a grassland.

Step II: Data from the special meteorological points were compared with the data from the reference climatological stations of CHMI using regression analysis. Regression relationships can be used for spot modelling of temperature and humidity under urban climate conditions. Based on the climatological data from the reference meteorological stations, it is possible even without direct measurements to estimate temperature and moisture conditions at the measuring points. The ten-minute data over 2011-2014 were evaluated using linear regression methods.

Step III: The impact of the local urban and micro-urban heat island on city residents and visitors was evaluated using the HUMIDEX index. HUMIDEX was used for the first time in 1965 in Canada to describe how hot the weather feels to the average person by combining the effect of heat and humidity. The index provides an indication of a citizen's perception of the outdoor air as a consequence of a lack of evaporation of perspiration during hot and humid weather (Ghanghermeh et al., 2013).

The following equation was used to calculate HUMIDEX:

$$
\text { HUMIDEX }=\mathrm{T}+(0.5555) \times(\mathrm{e}-10.0),
$$

where $\mathrm{T}=$ air temperature $\left({ }^{\circ} \mathrm{C}\right)$ and $\mathrm{e}=$ actual vapour pressure $(\mathrm{hPa})$.

An evaluation was conducted from August 2011 to September 2014. Only the months June, July and August were considered because temperature increases that might indicate potential discomfort did not occur in the remaining months.

Ten-minute temperature and humidity data were used to calculate hourly averages, and HUMIDEX was calculated based on the hourly averages. The actual vapour pressure e $[\mathrm{hPa}]$ was calculated from the temperature $\mathrm{T}\left[{ }^{\circ} \mathrm{C}\right]$ and relative humidity $\varphi[\%]$ data using well-known relationships. The HUMIDEX scale used in this study is presented in Tab. 2.

Step IV: Point measurements of air temperature and humidity (see Step I above) were interpolated using standard GIS methods (ArcGIS 10.3, ESRI, Redlands, California, USA). The layer of Coordination of Information on the Environment (CORINE) land cover (Heymann et al., 1994) from 2006 was converted into raster. The raster was then reclassified by attaching every single pixel to one of the six categories according to the supposed effect on air temperature and humidity. This method is commonly employed in climatology for the spatial expression of climatological variables. The method is based on the calculation of raster values from point measurements by regression relations between the investigated variable

\begin{tabular}{|l|l|}
\hline HUMIDEX range $\left({ }^{\circ} \mathbf{C}\right)$ & \multicolumn{1}{|c|}{ Degree of comfort } \\
\hline Less than 29 & Comfort \\
\hline $30-34$ & Some possible slight discomfort \\
\hline $35-39$ & Some possible moderate discomfort \\
\hline $40-45$ & Possible strong discomfort \\
\hline $46-53$ & Possible very strong discomfort \\
\hline Over 54 & Danger of death; imminent heat stroke \\
\hline
\end{tabular}

Tab. 2: HUMIDEX scale (after Baum et al., 2009) and the reclassified CORINE layer (Van Weverberg et al., 2008). The universal linear kriging method (Papritz and Stein, 2002; Zhang et al., 2011) was applied to interpolate the measured values of the temperature and the values calculated from the regression dependence. The resulting raster was then smoothed by a low pass filter.

Step V: Spatial heterogeneity was evaluated by using thermal satellite imagery. The output from thermal remote sensing was compared with and evaluated by ground monitoring results.

Surface temperature data were processed using a monowindow algorithm, which considers a single frame in a thermal spectrum. The mono-window algorithm for processing images from the LANDSAT-8 (TIRS sensor) satellite consists of two steps (Weng et al., 2004). In this case, the brightness temperature represents the temperature of an absolutely black body at a given wavelength and radiation intensity. Within a selected range, however, the earth does not behave as an ideal emitter, and its emissivity is extremely variable over space. Therefore, a correction is necessary. In accordance with Mallick et al. (2008), the emissivity correction used CORINE Land Cover 2012 (CLC 2012) classes with known average emissivity values.

\section{Results and discussion}

\section{1 Step $I$}

Table 3 shows that Locality 4 was warmest according to most of the temperature variables. This locality thus showed the highest urban heat island. Incoming solar radiation caused intensive warming of artificial surfaces at Localities 4 and 1 . The coldest point in terms of mean values was Locality 3 (by up to $5^{\circ} \mathrm{C}$ ). However the outstanding feature of this locality is higher thermoregulation of vegetation cover and thus the absolute minimum value was recorded in Locality 1 due to the surface emissivity.

Locality 2 had the most intense cooling effect during extremely high temperature episodes and had the smallest temperature amplitude. Locality 1 had the highest extreme values due to artificial surfaces. The (ir)regulation of solar radiation, albedo, emissivity and air temperature on the temperature of asphalt surfaces and near-surface air layer was previously reported in detail (Středa et al., 2011). The asphalt temperatures surpassed $70{ }^{\circ} \mathrm{C}$, particularly on days with significantly high levels of radiation.

The relative humidity is shown in Table 4 . Humidity at the typically humid Locality 3 rarely dropped below $40 \%$, and values higher than $95 \%$ prevailed. The typical night-time (day-time) value of $100 \%$ (lower than $100 \%$ ) at Locality 1 is associated with rapid cooling (warming) of the air. The dew point temperature was attained as a result of the cooling.

The evolution of the air temperatures and their differences on an extraordinary hot day are shown in Figure 2. The positive effects of the land cover at Localities 2, 3 and 5 on extreme temperature reductions are obvious. The air temperatures at Localities 1 and 4 were significantly higher than those measured at the CHMI reference station.

\subsection{Step II}

The relationship between the air temperature at the CHMI meteorological station (Locality 7) and the meteorological measurement in the city centre with the highest air temperature (Locality 4) was determined. The relationship $\left(r^{2}=0.9765\right)$ was characterized by the linear 


\begin{tabular}{|c|c|c|c|c|c|c|c|c|c|c|c|}
\hline 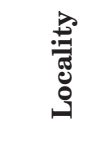 & $\begin{array}{l}\text { : } \\
\text { 奈 } \\
\text { z } \\
\text { z }\end{array}$ & $\sum^{\infty}$ & 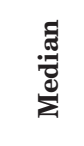 & $\stackrel{\Xi}{i}$ & $\sum^{ \pm}$ & 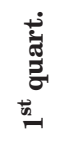 & 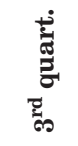 & 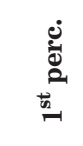 & 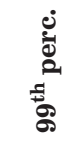 & 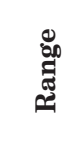 & $\begin{array}{l}\dot{\overrightarrow{0}} \\
\dot{\Delta}\end{array}$ \\
\hline 1 & 22323 & 11.0 & 10.8 & -22.6 & 39.5 & 3.8 & 17.6 & -7.5 & 32.1 & 62.2 & 9.2 \\
\hline 2 & 22320 & 10.6 & 11.0 & -19.1 & 35.7 & 3.6 & 17.0 & -7.0 & 29.1 & 54.8 & 8.5 \\
\hline 3 & 22102 & 9.7 & 9.6 & -22.5 & 37.3 & 2.7 & 16.0 & -8.1 & 29.9 & 59.7 & 8.8 \\
\hline 4 & 22319 & 12.0 & 12.1 & -17.7 & 41.1 & 4.7 & 18.6 & -6.6 & 33.3 & 58.8 & 9.3 \\
\hline 5 & 22320 & 11.0 & 11.2 & -18.6 & 36.2 & 4.2 & 17.4 & -7.1 & 30.0 & 54.8 & 8.7 \\
\hline 6 & 22322 & 10.4 & 10.6 & -20.1 & 36.8 & 3.6 & 16.9 & -8.1 & 30.0 & 56.9 & 8.8 \\
\hline 7 & 22024 & 10.7 & 10.8 & -18.4 & 37.2 & 4.0 & 17.0 & -7.5 & 30.0 & 55.6 & 8.7 \\
\hline
\end{tabular}

Tab. 3: Basic statistical analysis of the air temperature over the entire period (August 2011-October 2014). Note: maxima are in bold, minima are in italics. Source: authors

\begin{tabular}{|c|c|c|c|c|c|c|c|c|c|c|c|}
\hline 胥 & 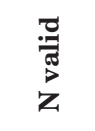 & $\sum^{\infty 00}$ & 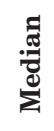 & 塄 & 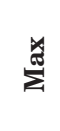 & 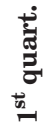 & 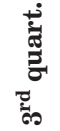 & 递 & 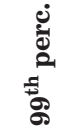 & 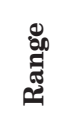 & 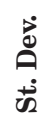 \\
\hline 1 & 20782 & 79 & 85 & 18 & 100 & 66 & 95 & 31 & 100 & 85 & 19 \\
\hline 2 & 20779 & 83 & 88 & 23 & 100 & 72 & 97 & 39 & 100 & 77 & 17 \\
\hline 3 & 22044 & 85 & 91 & 19 & 100 & 76 & 98 & 36 & 100 & 81 & 17 \\
\hline 4 & 20778 & 75 & 79 & 18 & 100 & 63 & 89 & 29 & 100 & 82 & 18 \\
\hline 5 & 20779 & 78 & 83 & 20 & 100 & 67 & 92 & 35 & 100 & 80 & 17 \\
\hline 6 & 22322 & 74 & 79 & 16 & 100 & 64 & 88 & 30 & 100 & 81 & 18 \\
\hline 7 & 22287 & 75 & 79 & 19 & 100 & 62 & 90 & 32 & 100 & 81 & 18 \\
\hline
\end{tabular}

Tab. 4: Basic statistical analysis of the air humidity over the entire period (August 2011-October 2014). Note: maxima are in bold, minima are in italics. Source: authors

regression equation $\mathrm{Y}=1.0594 \times \mathrm{X}+0.7285$ (where $\mathrm{Y}=$ air temperature at the measurement point, and $\mathrm{X}=$ air temperature at the CHMI standard meteorological station). As shown, air temperature can be quite easily modelled by regression models based on nearby meteorological stations, if available. Due to the low density of meteorological stations, air temperature modelling in small cities also requires sophisticated models employing variables such as: distance to the urban area, topographic position, land-cover diversity, building density and northness index (Ivajnššč et al., 2014).

The relationship between air humidity at these stations was defined by the linear regression equation $\mathrm{Y}=0.9503 \times \mathrm{X}+3.229$ (where $\mathrm{Y}=$ air humidity at the measurement point, and $\mathrm{X}=$ air humidity at the CHMI standard meteorological station). The dispersion values around the linear trend line were significantly larger compared with the air temperature. The coefficient of determination was high $\left(\mathrm{r}^{2}=0.8812\right)$, indicating a close relationship; however, modelling the relative humidity (based on simple regression using data from the reference station) resulted in significant errors and, therefore, the use of this procedure is limited.

\subsection{Step III}

In Step III, the HUMIDEX index was calculated for all sites during the months of June, July and August. Graphical and basic statistical evaluations are given in the box-plots (Fig. 3). The highest values were obtained at localities with

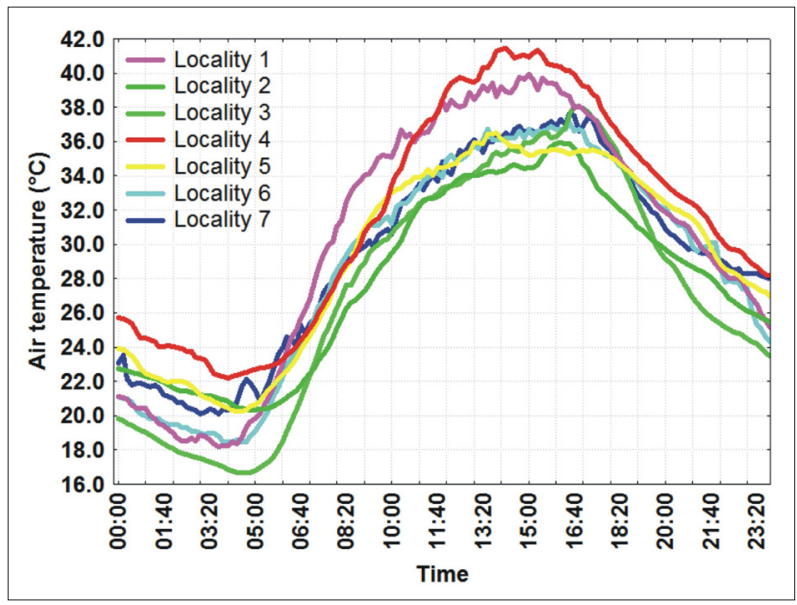

Fig. 2: Evolution of the air temperature during the hottest day (28 ${ }^{\text {th }}$ July 2013) Source: authors

the highest proportion of artificial surfaces (Locality 1 and Locality 4), as expected. The critical values were achieved only in rare extreme cases (less than $25 \%$ of all cases).

HUMIDEX limits of $35^{\circ} \mathrm{C}$ and $40-45^{\circ} \mathrm{C}$ have been proposed in Europe and Canada, respectively, to reduce the risks of excessive heat. Some results, however, show that HUMIDEX frequently results in an underestimation of the potential danger in the workplace and an unreliable comfort prediction occurs when this index is used in indoor situations (d'Ambrosio Alfano et al., 2011). 
The differences in the daily HUMIDEX between the sites are shown in Figure 4. In Locality 1, discomfort over artificial surfaces was first recorded in the early morning and then peaked in the afternoon. Discomfort in Locality 4 started approximately one hour later because enclosed spaces were shaded by buildings early in the morning. The daily evolution of discomfort in the forest (Locality 3) is interesting: until noon, the discomfort was identical to the CHMI stations, while in the afternoon, when the sensor was no longer overshadowed by trees, the frequency of discomfort increased significantly. This result corresponds fairly well with the findings of Litschmann and

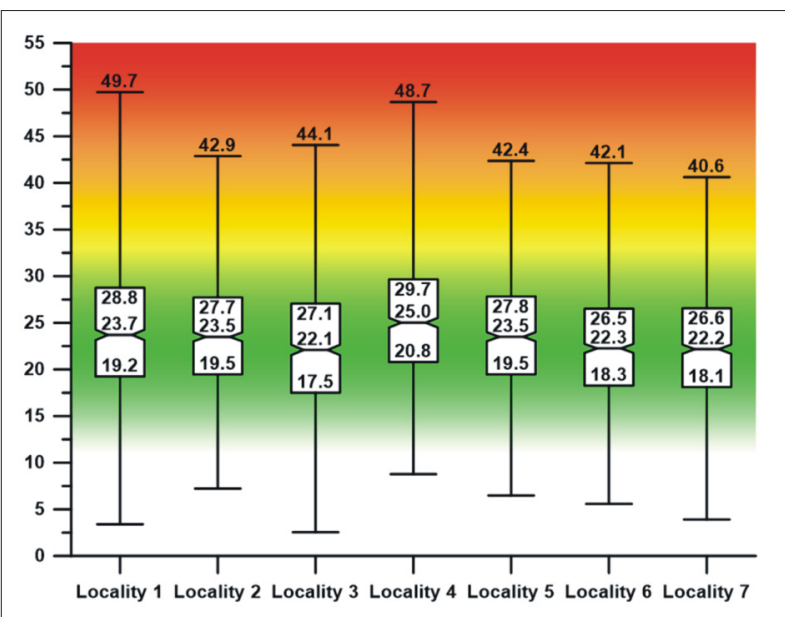

Fig. 3: The range of HUMIDEX values for each locality during July and August 2011-2014 (hourly data) and associated descriptive statistics (i.e., median, minimum, maximum, first quartile, and third quartile); plotted with Software Grapher, Golden Software, Colorado Source: authors
Hadaš (2003) and Mayer (1996). Mayer (1996) evaluated the effect of trees in street canyons in Munich (Germany) by comparing street canyons (north-south) with and without trees. This author reported a small effect on air temperature measured at a height of $1.10 \mathrm{~m}$ above ground level, but the physiologically equivalent temperature was reduced from $46^{\circ} \mathrm{C}$ to $31^{\circ} \mathrm{C}$, which reduced the heat stress by $40 \%$.

July had the highest incidence of discomfort based on the HUMIDEX index. Locality 4 contained the most extreme places, similar to the concrete and asphalt in Locality 1. August 2013 was the worst month in terms of thermal comfort (Tab. 5). In contrast, the summer of 2012 was characterized as relatively pleasant without significant extremes. Erratic values were recorded in 2014. Compared with other years, June and August were relatively cool with a low incidence of discomfort, while July was characterized by the highest frequency of discomfort.

\subsection{Step IV}

Detailed measurements of meteorological conditions in a heterogeneous urban environment are very expensive. Additionally, the meteorological components of a city cannot be measured at the level of detail required for bioclimatological assessments. Modelling appears to be the most appropriate method to generate the data needed for urban planning purposes with the aim of creating and safeguarding healthy conditions. Re-designing a city on a large scale is typically illusionary, however, and planning measures are usually restricted to a small part of a city (Koppe et al., 2004).

The spatial expression of point measurements of air temperature is obtained using the CORINE layer and GIS interpolation method, as shown in Figure 5. Although the expression generalizes the air temperature distribution, the air temperature difference between the city centre and
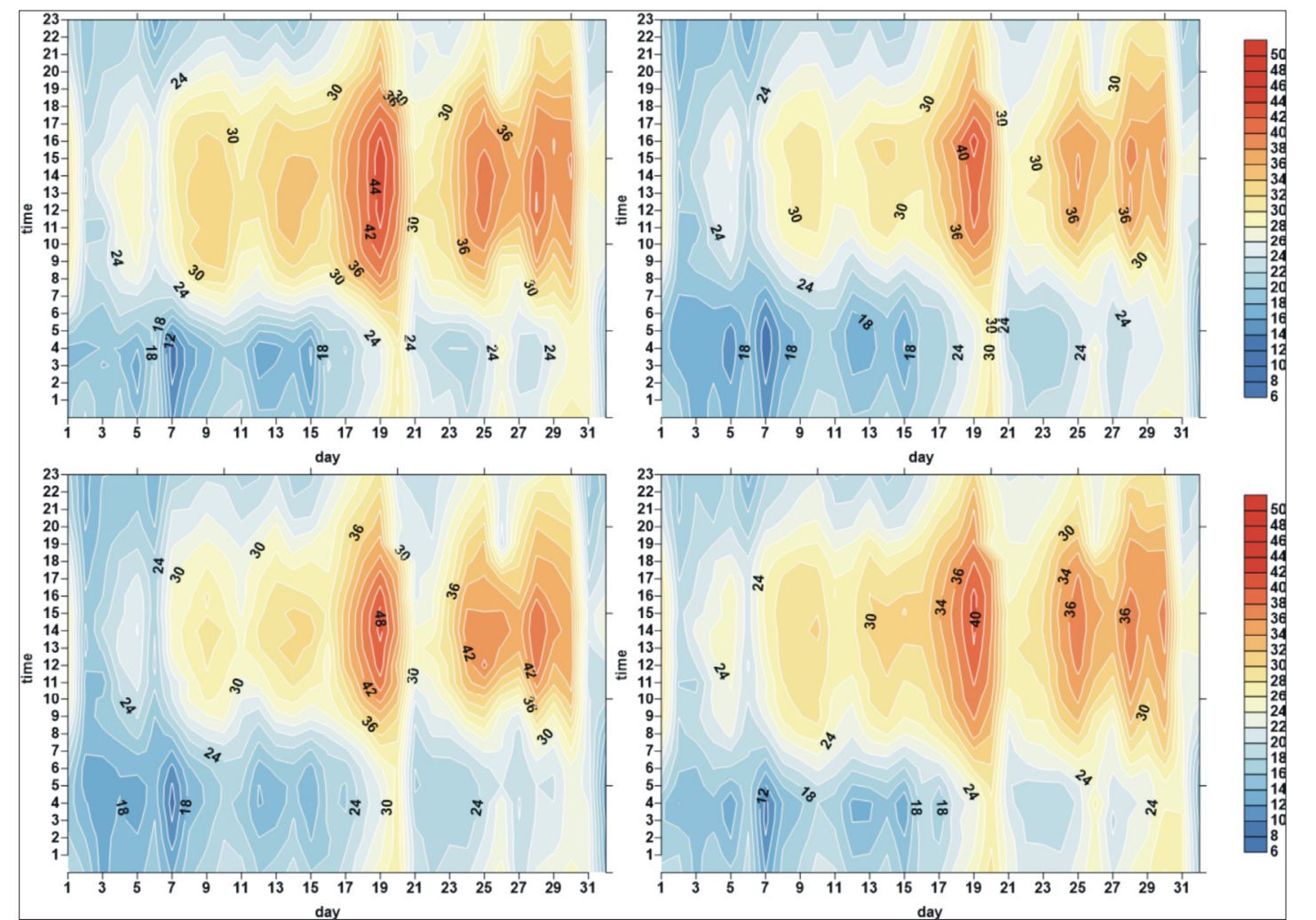

Fig. 4: 24-hour HUMIDEX values (Y axis) at selected locations (Locality 1 - upper left, Locality 2 - upper right, Locality 4 - bottom left, and Locality 6 - bottom right) from July 10, 2013 - August 10, 2013 (X axis); plotted with Software Surfer, Golden software, Colorado. Source: authors 


\begin{tabular}{|c|c|c|c|c|c|c|c|c|c|}
\hline Year & Month & Locality 1 & Locality 2 & Locality 3 & Locality 4 & Locality $\mathbf{5}$ & Locality $\mathbf{6}$ & Locality 7 & Average \\
\hline 2011 & VIII & 15 & 14 & 7 & 23 & 17 & 14 & 15 & $\mathbf{1 5}$ \\
\hline 2012 & VI & 11 & 11 & 10 & 15 & 10 & 8 & 8 & $\mathbf{1 0}$ \\
\hline 2012 & VII & 19 & 15 & 15 & 19 & 14 & 12 & 12 & $\mathbf{1 5}$ \\
\hline 2012 & VIII & 19 & 12 & 11 & 23 & 13 & 10 & 10 & $\mathbf{1 4}$ \\
\hline 2013 & VI & 14 & 10 & 10 & 17 & 10 & 8 & 9 & $\mathbf{1 1}$ \\
\hline 2013 & VII & 24 & 16 & 15 & 28 & 15 & 9 & 10 & $\mathbf{1 7}$ \\
\hline 2013 & VIII & 39 & 33 & 31 & 41 & 36 & 31 & 30 & $\mathbf{3 4}$ \\
\hline 2014 & VI & 8 & 6 & 7 & 11 & 7 & 6 & 6 & $\mathbf{7}$ \\
\hline 2014 & VII & 27 & 22 & 21 & 32 & 23 & 14 & 14 & $\mathbf{2 2}$ \\
\hline 2014 & VIII & 9 & 5 & 6 & 10 & 6 & 4 & 4 & $\mathbf{6}$ \\
\hline \multicolumn{2}{|c|}{ Average } & $\mathbf{1 8}$ & $\mathbf{1 4}$ & $\mathbf{1 3}$ & $\mathbf{2 2}$ & $\mathbf{1 5}$ & $\mathbf{1 2}$ & $\mathbf{1 2}$ & $\mathbf{1 5}$ \\
\hline
\end{tabular}

Tab. 5: Relative frequency (\%) of HUMIDEX categories relating to "some possible moderate discomfort", "possible strong discomfort" and "possible very strong discomfort" in individual months.

Source: authors

surroundings is obvious. The cooling effect of vegetation and water bodies is also shown. Manik and Syaukat (2015) applied a similar approach (i.e. GIS interpolation of insitu monitoring data and CORINE layer with subsequent comparison with remote sensing - see Step V) in their analysis of the spatial distribution of air temperature in Bandar Lampung and Jakarta. With respect to urban environment heterogeneity, its area and relatively low number of meteorological stations, however, the mapping expression and distribution of temperature or air humidity using the CORINE layer is only generalized output with simple orientation information value. To maximize the informative value, more punctual data of land cover in GIS are needed. The precise modelling of urban microclimate requires a combination of in-situ measurement with microclimate simulation tools.

During a hot day (20 $0^{\text {th }}$ August 2012; Fig. 5), the daytime air temperature difference between central and suburban parts of Hradec Králové exceeded $5{ }^{\circ} \mathrm{C}$ and $4{ }^{\circ} \mathrm{C}$ during the night. As a comparative example, the maximum night difference between central Łodź and nearby suburban areas reached $8{ }^{\circ} \mathrm{C}$ in winter (Fortuniak et al., 2006).

\subsection{Step V}

The spatial heterogeneity of the surface temperature in Hradec Králové and its surroundings was evaluated using remote sensing. The results of the satellite thermal- image evaluation (July 27, 2013, 9:53 GMT) are presented in Table 6 and Figure 6. The absolute highest surface temperature $\left(39.9^{\circ} \mathrm{C}\right)$ was recorded at Locality 5 , and the lowest $\left(31.9^{\circ} \mathrm{C}\right)$ was recorded at Locality 2 .

The surface temperature at Locality 5 was influenced by an industrial zone, highways and building surfaces. The characteristics of the residential area and greenery, however, reduced the air temperature at ground level.

An analysis of the surface characteristics, as represented by the amount of vegetation cover, demonstrates the control of the land surface temperature variability (56-67\% of the explained variance) by the degree of urbanisation, which was represented by building density (37-40\% of the land surface temperature variance), following Dobrovolný (2013).

A correlation analysis revealed a relationship between both the surface temperature and immediate air temperature, where $r=0.784$ or $r=0.985$, respectively, upon exclusion of Locality 5 (i.e. the locality with a heterogeneous habitat; therefore thermal remote sensing is likely to be influenced by the sensor resolution). The correlation coefficient between surface temperature and the air temperature sum (Kyselý et al., 2000) and air average temperature (from midnight to 9:53 GMT) was 0.696 and 0.707 , respectively. The correlation coefficient between the immediate and average air moisture was -0.519 and -0.475 , respectively. A similar temperature pattern was

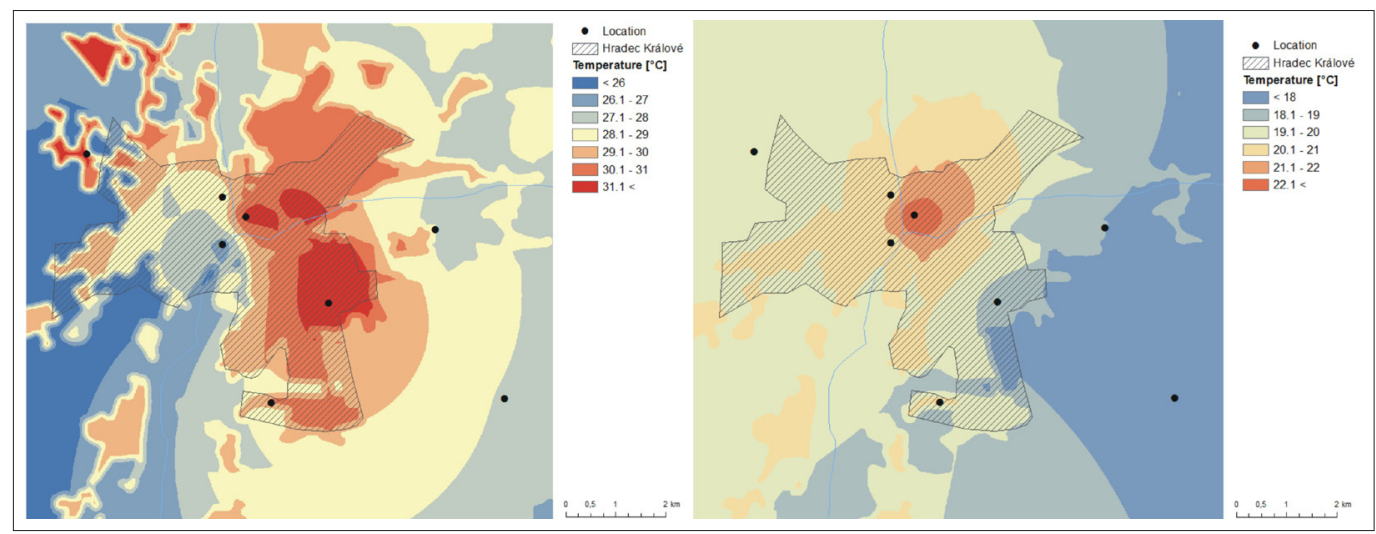

Fig. 5: Average air temperature during the day (left) and night (right) of a hot day

Source: authors 


\begin{tabular}{|l|c|c|c|c|c|c|c|}
\hline & Locality $\mathbf{1}$ & Locality $\mathbf{2}$ & Locality $\mathbf{3}$ & Locality 4 & Locality $\mathbf{5}$ & Locality 6 & Locality 7 \\
\hline Instantaneous air temperature $\left({ }^{\circ} \mathrm{C}\right)$ & 35.3 & 29.8 & 30.1 & 34.1 & 32.1 & 31.8 & 31.6 \\
\hline Instantaneous air humidity $(\%)$ & 34 & 53 & 48 & 40 & 44 & 36 & 37 \\
\hline Air temperature sum $\left({ }^{\circ} \mathrm{C}\right)$ & 1502 & 1413 & 1299 & 1582 & 1489 & 1418 & 1448 \\
\hline Average air temperature $\left({ }^{\circ} \mathrm{C}\right)$ & 22.8 & 21.4 & 19.7 & 24.0 & 22.6 & 21.5 & 21.9 \\
\hline Average air humidity $(\%)$ & 73 & 77 & 83 & 65 & 70 & 70 & 66 \\
\hline TRS surface temperature $(\%)$ & 38.7 & 31.9 & 32.9 & 37.4 & 39.9 & 35.3 & 33.8 \\
\hline
\end{tabular}

Tab. 6: Meteorological conditions of measurement localities in terms of thermal remote sensing (TRS) Source: authors

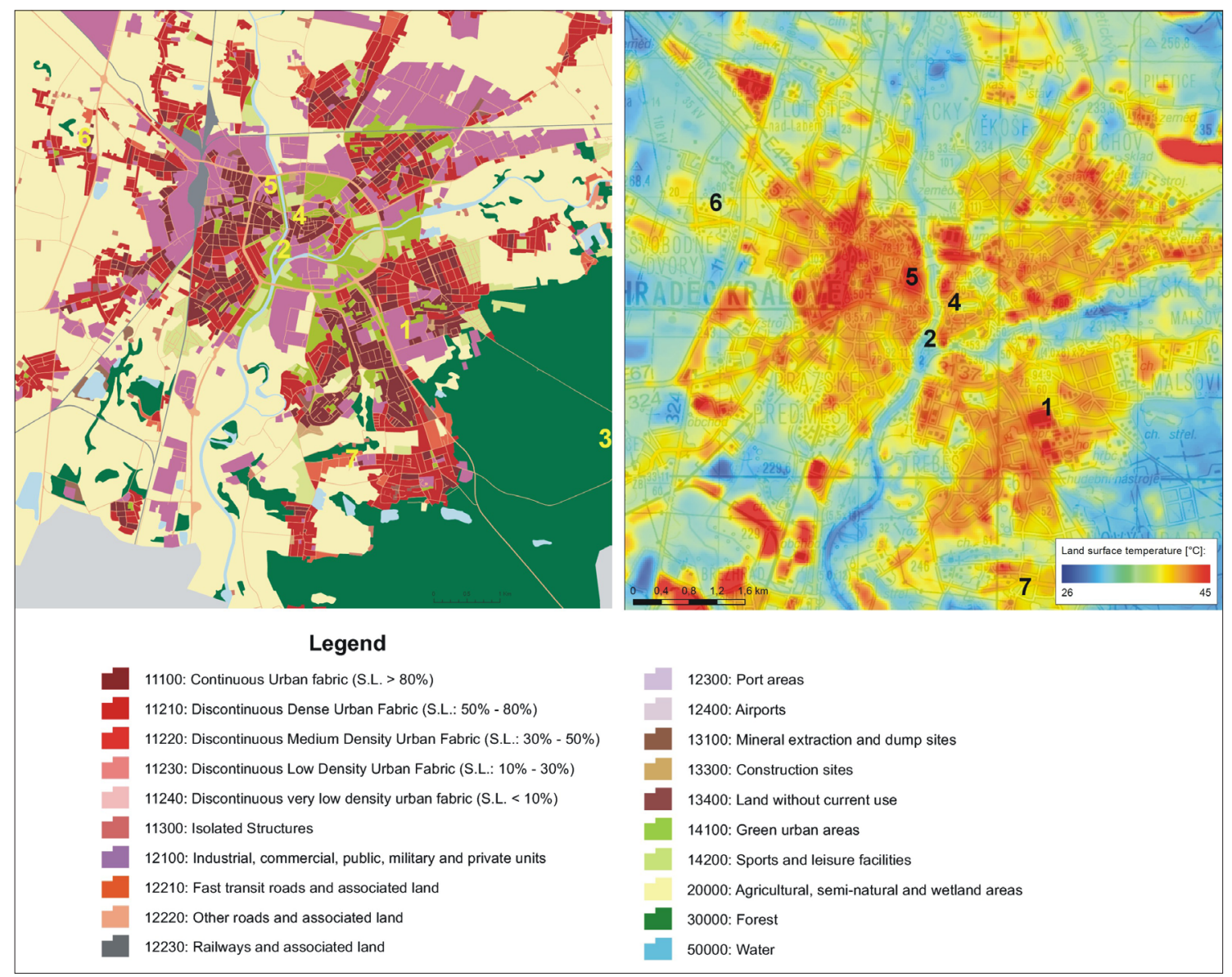

Fig. 6: Satellite thermal image of Hradec Králové and adjacent surroundings with measurement locality network (right part) and land cover map (left part)

Source: Left part with legend: CORINE layer; Right part: LANDSAT-8, scene LC81910252013208LGN00 and authors

obtained by interpolating point measurements (Fig. 5). In contrast, Geletič and Vysoudil (2012) compared the surface temperature field with the air temperature recorded at weather stations within and near the city of Olomouc. Their analysis showed that the description of spatial differences in surface temperatures of a city and its surroundings, based on an evaluation of thermal imagery, was inconclusive. Soil temperature data series measured at selected stations of the same metropolitan station system of Olomouc were analysed by Lehnert (2013), but the impact of the urban landscape on the soil temperature regime was not demonstrated.

\section{Conclusions and policy implications}

Local governments have limited possibilities of influencing climate change mitigation, with measures such as education, taxes, a fee policy, and other economic instruments (incentives or disincentives). The greatest influence of local governments, however, is evident in their decisions on urban form, primarily through urban planning and land use regulation. The methodology for urban climate study demonstrated here, with the necessary data processing, should be a worthwhile tool for local authorities. Such a unified methodology can be employed to develop a theoretical basis for better urban planning policies to mitigate the urban heat island effects.

Some of the constituent activities could be as follows:

a. Pre-screening based on thermal images and land-use to determine the crucial places for direct monitoring;

b. Establishment of a monitoring network, monitoring as such (for at least two years), and subsequent use of regression analysis with the existing (reference) measurements. In-situ meteorological monitoring is 
indispensable for precise meteorological monitoring and model verification as well. Air temperatures at locations of interest can be subsequently modelled with a high degree of reliability using regression relationships. In addition, the effect of land cover was reflected in the humidity relationships, although modelling relative humidity using only simple regression results in relatively large errors;

c. Calculation of climatological variables including bioclimatological ones (with direct connections for humans) such as the HUMIDEX index. Climate considerations often have little effect on urban planning. Although urban planners are interested in climatic aspects, the use of climate information has low priority. This is why taking the HUMIDEX values into consideration can change practice, as its influences on humans are more understandable than temperature conditions as such; and

d. The spatial expression of point air temperature and humidity measurements is enabled by GIS methods, but with limited accuracy due to urban environment heterogeneity and the density of the monitoring network.

\section{Acknowledgement}

This study was supported by a project of the Ministry of Agriculture (NAZV QJ1230056): "The impact of the expected climate changes on soils of the Czech Republic and the evaluation of their productive functions". The authors would like to thank the anonymous reviewers for their helpful and constructive comments that greatly contributed to improving the final version of the paper. They would also like to thank the editors for their comments and support during the review process.

\section{References:}

ANIELLO, C., MORGAN, K., BUSBEY, A., NEWLAND, L. (1995): Mapping micro-urban heat islands using LandsatTM and GIS. Computers and Geosciences, 21(8): 965-969.

BAUM, S., HORTON, S., CHOY, D. L., GLEESON, B. (2009): Climate change, health impacts and urban adaptability: Case study of Gold Coast City. Urban Research Program, Research Monograph 11. Brisbane, Griffith University.

BOKWA, A. (2011): The urban heat island in Kraków, Poland: interaction between land use and relief. Moravian Geographical Reports, 19(3): 2-7.

BOKWA, A., LIMANÓWKA, D. (2014): Effect of relief and land use on heat stress in Kraków, Poland. Die Erde, 145(1-2): 34-48.

BOTTYÁN, Z., UNGER, J. (2003): A multiple linear statistical model for estimating the mean maximum urban heat island. Theoretical and Applied Climatology, 75: 233-243.

d'AMBROSIO ALFANO, F. R., PALELLA, B. I., RICCIO, G. (2011): Thermal Environment Assessment Reliability Using Temperature - Humidity Indices. Industrial Health, 49: 95-106.

DESSAI, S. (2002): Heat stress and mortality in Lisbon Part I. model construction and validation. International Journal of Biometeorology, 7(1): 6-12.

ELLEFSEN, R. (1991): Mapping and measuring buildings in the canopy boundary layer in the U.S. cities. Energy and Buildings, 15-16(3-4): 1025-1049.
EKŞI, M., UZUN, A. (2013): Investigation of thermal benefits of an extensive green roof in Istanbul climate. Scientific research and essays, 8(15): 623-632.

DOBROVOLNÝ, P. (2013): The surface urban heat island in the city of Brno (Czech Republic) derived from land surface temperatures and selected reasons for its spatial variability. Theoretical and Applied Climatology, 112(1-2): 89-98.

FORTUNIAK, K., KŁYSIK, K., WIBIG, J. (2006): Urbanrural contrasts of meteorological parameters in Łodź. Theoretical and Applied Climatology, 84: 91-101.

FRICH, P., ALEXANDER, L., DELLA-MARTA, P., GLEASON, B., HAYLOCK, M., KLEIN, TANK, A., PETERSON, T. (2002): Observed coherent changes in climatic extremes during the second half of the twentieth century. Climate Research, 19: 193-212.

GELETIČ, J., VYSOUDIL, M. (2012): Analysis of surface temperatures in urban and suburban landscapes from satellite thermal images: a case study of Olomouc and its environs, Czech Republic. Moravian Geographical Reports, 20(1): 2-15.

GHANGHERMEH, A., ROSHAN, G., OROSA, J. A., CALVOROLLE, J. L., COSTA, A. M. (2013): New Climatic Indicators for Improving Urban Sprawl: A Case Study of Tehran City. Entropy, 15: 999-1013.

HEYMANN, Y., STEENMANS, C., CROISILLE, G., BOSSARD, M. (1994): CORINE land cover technical guide. Office for Official Publications of the European Communities, Luxembourg.

HUANG, Y. J., AKBARI, H., TAHA, H., ROSENFELD, A. H. (1987): The potential of vegetation in reducing summer cooling loads in residential buildings. Journal of Climate and Applied Meteorology, 26: 1103-1116.

IVAJNŠIČ, D., KALIGARIČ, M., ŽIBERNA, I. (2014): Geographically weighted regression of the urban heat island of a small city. Applied Geography, 53: 341-353.

JENDRITZKY, G. (1988): Bioklima. VDI Kommission Reinhaltung der Luft, ed. Stadtklima und Luftreinhaltung. Springer Verlag, Berlin.

JENDRITZKY, G., GRÄTZ, A., KOPPE, C., LASCHEWSKI, G. (2003): How to deal with the urban development, urban climate, human health effect relationship - a contribution to methodology. Proceedings Fifth International Conference on Urban Climate, (p. 47-50), Lodz, Poland.

JENDRITZKY, G., NÜBLER, W. (1981): A model analysing the urban thermal environment in physiologically significant terms. Archives for meteorology, geophysics, and bioclimatology, Series B, 29(4): 313-326.

KARL, T., KNIGHT, R. (1997): The 1995 Chicago heat wave: How likely is a recurrence? Bulletin of American Meteorological Society, 78(6): 1107-1119.

KOPPE, C., KOVATS, S., JENDRITZKY, G., MENNE, B. (2004): Heat-waves: risks and responses. Health and Global Environmental Change Series, No. 2, Europe, World Health Organization.

KYSELÝ, J., KALVOVÁ, J., KVĚTOŇ, V. (2000): Heat waves in the South Moravian region during the period 1961-1995. Studia Geophysica et Geodaetica, 44(1): 57-72. 
LAMBIN, E. F., GEIST, H. J. (2006): Land-use and Landcover change. Local processes and global impacts. Berlin, Springer-Verlag.

LANDSBERG, E. H. (1981): The urban climate. International geophysics series, Vol. 28. New York, Academic press.

LEHNERT, M. (2013): The soil temperature régime in the urban and suburban landscapes of Olomouc, Czech Republic. Moravian Geographical Reports, 21(3): 27-36.

LEHNERT, M., GELETIČ, J., HUSÁK, J., VYSOUDIL, M. (2014): Urban field classification by "local climate zones" in a medium-sized Central European city: the case of Olomouc (Czech Republic). Theoretical and Applied Climatology, DOI 10.1007/s00704-014-1309-6 (in print).

LITSCHMANN, T., HADAŠ, P. (2003): Mikroklima vybraných porostních stanovište. In: Rožnovský, J., Litschmann, T. [ed.]: Seminář „Mikroklima porostů“, Brno, 26. března 2003, (p. 59-65), Brno, ČBkS.

MALLICK, J., KANT, Y., BHARATH, B. D. (2008): Estimation of land surface temperature over Delhi using Landsat-7 ETM+. Journal of Indian Geophysical Union, 12(3): 131-140.

MANIK, T. K., SYAUKAT, S. (2015): The impact of urban heat islands. Assessing vulnerability in Indonesia. Asian Cities Climate Resilience, Working Paper Series No. 13. London, IIED.

MAYER, H. (1996): Human-biometeorologische Probleme des Stadtklimas. Geowissenschaften, 14(6): 233-239.

OKE, T. R. (1997): Part 4: The changing climatic environments. Urban climates and global environmental change. In: Thompson, R. D. and Perry, A. [eds.]: Applied climatology principles and practice (pp. 273-287). Routledge, London.

OKE, T. R. (1982): The energetic basis of the urban heat island. Quarterly Journal of the Royal Meteorological Society, 108(455): 1-24.

OKE, T. R. (2006): Initial guidance to obtain representative meteorological observations at urban sites. Instruments and Observing Methods, Report No. 81. Geneva, WMO.

PAPRITZ, A., STEIN, A. (2002): Spatial prediction by linear kriging. Spatial Statistics for Remote Sensing. Remote Sensing and Digital Image Processing, 1: 83-113.

POKLADNÍKOVÁ, H., FUKALOVÁ, P., ROŽNOVSKÝ, J., STŘEDA, T. (2009): Specifics of temperature extremes in the conditions of the urban climate. In: Pribullová, A., Bičárová, S. [eds.]: Sustainable development and bioclimate (pp. 217-218). Stará Lesná: Geophysical Institute of the SAS and SBkS.

SCHÄR, C., VIDALE, P.L., LÜTHI, D., FREI, C., HÄBERLI, C., LINIGER, M. A., APPENZELLER, C. (2004): The role of increasing temperature variability in European summer heat waves. Nature, 427: 332-336.

SMARGIASSI, A., GOLDBERG, M. S., PLANTE, C., FOURNIER, M., BAUDOUIN, Y., KOSATSKY, T. (2009): Variation of daily warm season mortality as a function of micro-urban heat islands. Journal of Epidemiology and Community Health, 63(8): 659-664.

SOUCH, C., GRIMMOND, S. (2006): Applied climatology: Urban climate. Progress in Physical Geography, 30(2): 270-279.
SRIVANIT, M. (2013): Integrated urban thermal environment assessment methods for multi-scale spatial planning. Ph.D. thesis. Department of Science and Advanced Technology Graduate School of Science and Engineering. Saga University, Japan.

SRIVANIT, M, HOKAO, K. (2013): Evaluating the cooling effects of greening for improving the outdoor thermal environment at an institutional campus in the summer. Building and Environment, 66: 158-172.

STATHOPOULOU, M., CARTALIS, C., KERAMITSOGLOU, I. (2004): Mapping micro-urban heat islands using NOAA/ AVHRR images and CORINE Land Cover: an application to coastal cities of Greece. International Journal of Remote Sensing, 25(12): 2301-2316.

STEWART, I. D. (2011): A systematic review and scientific critique of methodology in modern urban heat island literature. International Journal of Climatology, 31: $200-217$.

STEWART, I. D., OKE, T. R. (2012): Local climate zones for urban temperature studies. Bulletin of American Meteorological Society, 93(12): 1879-1900.

STŘEDA, T., STŘEDOVÁ, H., ROŽNOVSKÝ, J. (2011): Microclimate of tourist attractive areas of Brno City. In: Fialová, J., Pernicová, D. [eds.]: Public Recreation and Landscape Protection - Hand in Hand? Conference proceedings (pp. 78-84). Brno, Mendel University in Brno.

STŘEDA, T., STŘEDOVÁ, H., ŠEDIVÁ, I. (2014): Bioclimatic conditions for the recreationally important areas in the medium sized city. In: Fialová, J., Pernicová, D. [eds.]: Public Recreation and Landscape Protection - Hand in Hand? Conference proceedings (pp. 47-51). Brno, Mendel University in Brno.

SZÜCS, Á. (2013): Wind comfort in a public urban space Case study within Dublin Docklands. Frontiers of Architectural Research, 2: 50-66.

TAN, J., ZHENG, Y., SONG, G., KALKSTEIN, L. S., KALKSTEIN, A. J., TANG, X. (2007): Heat wave impacts on mortality in Shanghai, 1998 and 2003. International Journal of Biometeorology, 51(3): 193-200.

VAN WEVERBERG, K., DE RIDDER, K., VAN ROMPAEY, A. (2008): Modeling the contribution of the Brussels heat island to a long temperature time series. Journal of Applied Meteorology and Climatology, 47: 976-990.

VOOGT, J. A. (2002): Urban heat island. In: Douglas, I. [ed.]: Encyclopedia of global environmental change, Volume 3, Causes and consequences of global environmental change (pp. 660-666). Wiley.

VOOGT, J. A., OKE, T. R. (2003): Thermal remote sensing of urban climates. Remote Sensing of the Environment, Vol. 86, p. 370-384.

VYSOUDIL, M., LÉTAL, A., PAVELKOVÁ, R. (2009): Thermal monitoring: Identification tool of natural disasters risks response to local climatic effects. In: Proceedings, $33^{\text {rd }}$ International Symposium on Remote Sensing of Environment, ISRSE 2009 (pp. 571-574), Code 97459. Stresa; Italy.

VYSOUDIL, M., OGRIN, D. (2009): Portable infrared camera as a tool in topoclimatic research. Dela, 31: 115-127. 
WENG, Q., LU, D., SCHUBRING, J. (2004): Estimation of land surface temperature - vegetation abundance relationship for urban heat island studies. Remote Sensing of Environment, 89: 467-483.

WHO (2013): Annual report 2013. WHO Centre for Health Development, Kobe, Japan.
ZHANG, K., OSWALD, E. M., BROWN, D. G., BRINES, S. J., GRONLUND, C. J., WHITE-NEWSOME, J. L., ROOD, R. B., O'NEILL, M. S. (2011): Geostatistical exploration of spatial variation of summertime temperatures in the Detroit metropolitan region. Environmental Research, 111: 1046-1053.

Initial submission 17 December 2014, final acceptance 20 May 2015

Please cite this article as:

STŘEDOVÁ, H., STŘEDA, T., LITSCHMANN, T. (2015): Smart tools of urban climate evaluation for smart spatial planning. Moravian Geographical Reports, 23(3): 47-56. DOI: 10.1515/mgr-2015-0017. 